\title{
Toxicity of Hyperbaric Oxygen to Bacteria in Relation to the Cell Cycle and Catalase Synthesis
}

\author{
By G. D. GIFFORD \\ Department of Botany, University of Exeter
}

(Accepted for publication 26 January 1968)

SUMMARY

Growth of Bacillus subtilis and of Escherichia coli following treatment with oxygen at $\mathrm{to}$ atmospheres for $\mathrm{I} 8 \mathrm{hr}$ was synchronous. Treatment at lower pressures resulted in a much lower degree of synchrony. After exposure to high-pressure oxygen to induce synchronous growth of $B$. subtilis the resistance of various stages of the cell cycle to further treatment with oxygen at Io atm. was studied. Maximum resistance occurred immediately following division of the bacilli and then fell to a low value. The region of maximum resistance in $B$. subtilis compared fairly closely with the time of maximum catalase activity.

\section{INTRODUCTION}

Pritchard \& Hudson (1967) showed that induction of catalase occurred in cultures of Mucor racemosus and Candida utilis when exposed to high-pressure oxygen (HPO) for periods of up to 20 days. It was suggested that this might provide a mechanism for preventing peroxide accumulation, thus inducing resistance to high pressure oxygen toxicity. The results presented in the present paper describe the changes in catalase activity of Bacillus subtilis when exposed to Io atm. oxygen and the relation between resistance and physiological state at the time of pressure increase.

\section{METHODS}

Bacterial strains. Bacillus subtilis $\mathrm{NCIB} 36$ Io and Escherichia coli $\mathrm{B}$ I3 were obtained from the culture collection of the Department.

Media and cultivation. Bacteria were maintained on malt agar at $25^{\circ}$. Cultures for HPO treatment were grown in $25 \mathrm{ml}$. liquid glucose glutamate medium (Pritchard, $1965)$ in $100 \mathrm{ml}$. Erlenmeyer flasks at $37^{\circ}$ on a rotary shaker. For Escherichia coli the medium was supplemented with $0.5 \%(\mathrm{w} / \mathrm{v})$ casein hydrolysate.

Catalase determination. Bacteria for catalase determination were sedimented by centrifugation, resuspended in $4 \mathrm{ml}$. cold $0.05 \mathrm{M}$-phosphate buffer $(\mathrm{pH} \mathrm{6.8)}$ and disrupted by ultrasonic treatment. The material was centrifuged for $10 \mathrm{~min}$. at $30,000 \mathrm{~g}$ and the catalase activity of the supernatant fluid determined by the method of Herbert (1954). Enzyme activity is expressed per g. extracted protein.

Protein determination. Soluble protein was determined by the Folin phenol method of Lowry, Rosebrough, Farr \& Randall (I95I).

Bacterial counts. Total counts were made by using a bacterial counting chamber, $0.02 \mathrm{~mm}$. deep, with Thoma ruling.

Viable counts. Survival following HPO treatment was determined by dispensing in 
triplicate, $0.2 \mathrm{ml}$. samples of serially diluted culture on to malt agar in Petri dishes. Colonies were counted after $24 \mathrm{hr}$. incubation at $37^{\circ}$.

Pressure vessels. Cultures were subjected to pressure in steel pressure vessels similar to those described by Caldwell (I956).

\section{RESULTS}

Survival and catalase activity of Bacillus subtilis cultures subjected to HPO

Cultures $(6 \mathrm{hr})$ were subjected to Io atm. HPO and samples assayed for catalase activity after 24 and $48 \mathrm{hr}$ exposure. There was a decrease in catalase activity after $24 \mathrm{hr}$, though by $48 \mathrm{hr}$ the value had risen again. In a second experiment catalase activity was determined after 24,72 and $\mathrm{I} 44 \mathrm{hr}$ exposures. There was again a decrease

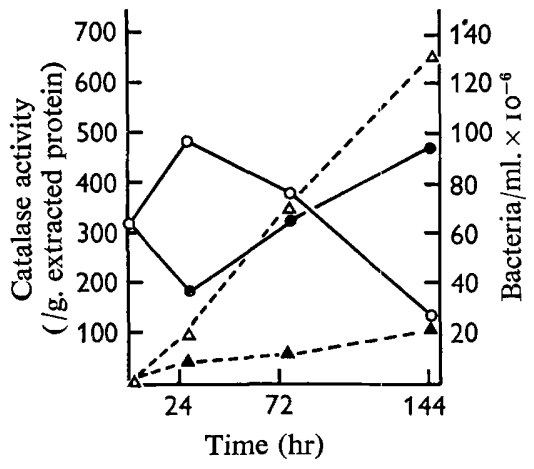

Fig. I

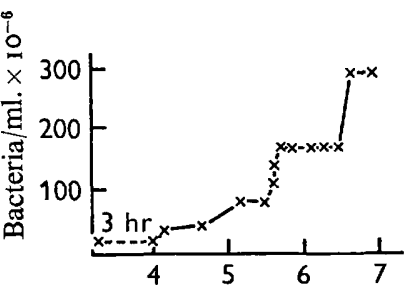

Time from inoculation (hr)

Fig. 2

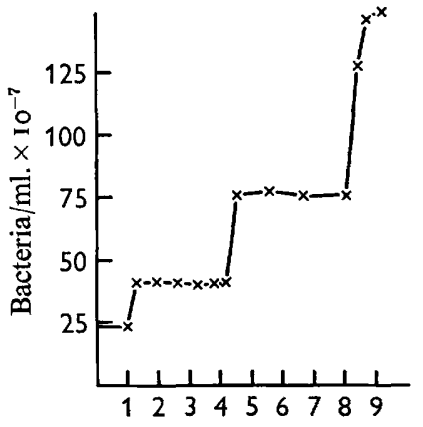

Time from inoculation (hr)

Fig. 3

Fig. I. Effect of treatment with ro atm. pure oxygen on catalase activity and growth of Bacillus subtilis. $\bigcirc-\mathrm{O}$, Catalase activity in air; - , catalase activity under oxygen; $\triangle-\triangle$, growth in air; $\mathbf{\Delta}--\Delta$, growth under oxygen.

Fig. 2. Growth of Bacillus subtilis in air, following $18 \mathrm{hr}$ exposure to oxygen at $10 \mathrm{~atm}$.

Fig. 3. Growth of Escherichia coli in air, following $18 \mathrm{hr}$ exposure to oxygen at io atm.

in activity in the first $24 \mathrm{hr}$, followed by a continued increase (Fig. I). Bacterial numbers, as determined by viable counts, showed a steady increase under HPO and indicated that after $48 \mathrm{hr}$ the catalase content per organism was considerably higher than that of the control organisms grown in air. In a similar experiment with an $18 \mathrm{hr}$ culture almost complete lysis occurred after $24 \mathrm{hr}$, thus preventing the determination of cellular catalase activity. The same result was obtained when the experiment was repeated.

\section{Synchrony of growth following HPO treatment}

Cultures $(6 \mathrm{hr})$ of Bacillus subtilis were subjected to oxygen at $2 \cdot 5,5 \cdot 0,7 \cdot 5$ and Io atm. for $18 \mathrm{hr}$ and their growth upon subsequent inoculation into $300 \mathrm{ml}$. of aerated medium at $37^{\circ}$ followed by direct counts. Following treatment with oxygen at Io atm., but not at the lower pressures, growth was synchronous (Fig. 2); this was confirmed in other experiments at $10 \mathrm{~atm}$. It was noted that some individuals elongated but did not divide. Growth upon inoculation into fresh medium was not immediate but began after a lag period of about $3 \mathrm{hr}$. After exposure to oxygen at pressures lower than Io atm. growth was not markedly synchronous although at 
$7.5 \mathrm{~atm}$. the growth curve did exhibit some indication of synchrony. The lag period was shorter at the lower pressures being about $1.5 \mathrm{hr}$ at $5 \mathrm{~atm}$. and $7.5 \mathrm{~atm}$. and virtually absent after treatment at $\mathbf{2 . 5} \mathrm{atm}$.

Treatment at Io atm. was also done with a $24 \mathrm{hr}$ culture of Escherichia coli. Growth upon return to air was again synchronous, apparently without a lag period (Fig. 3).

\section{Resistance of various stages of the cell cycle to HPO}

Samples were taken at $5 \mathrm{~min}$. intervals during one generation of an oxygen-induced synchronous culture and placed under oxygen at Io atm. In order to expose the bacteria as quickly as possible to the effects of HPO, $5 \mathrm{ml}$. samples were placed into $100 \mathrm{ml}$. Erlenmeyer flasks and the pressure raised in Io-I $5 \mathrm{sec}$. After I $8 \mathrm{hr}$ the pressure was released and survival determined by plate counts. All experiments showed that

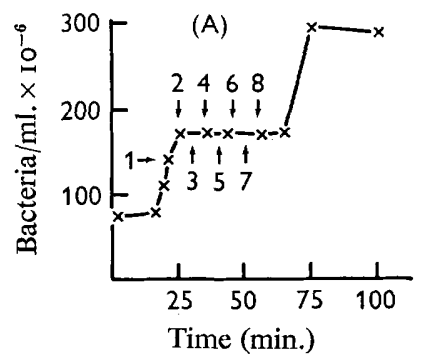

Time (min.)

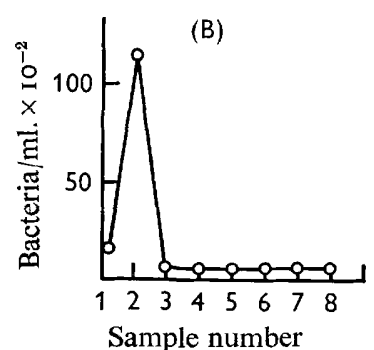

Fig. 4

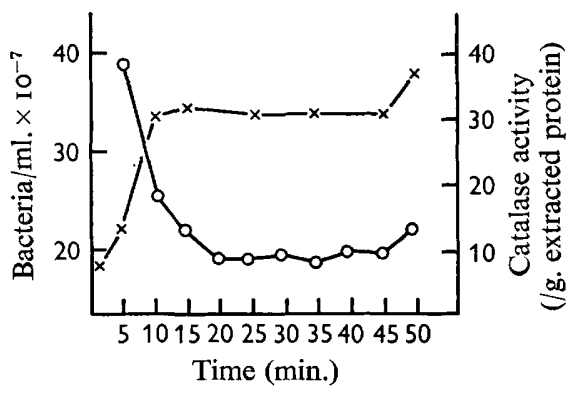

Fig. 5

Fig. 4. Survival of Bacillus subtilis exposed to HPO at different stages of the cell cycle. (A) Initial population showing when samples were taken for treatment with oxygen at Io atm. for $18 \mathrm{hr}$. (B) Survival (by plate counts) following treatment.

Fig. 5. Catalase activity in relation to the cell cycle. $\mathrm{O}-\mathrm{O}$, Catalase activity. $\times-\times$, Bacterial numbers.

maximum survival was restricted to the early part of the cell cycle immediately following division (Fig. 4), though there was a discrepancy between the maximum number of organisms surviving the HPO treatment $\left(c . \mathrm{IO}^{4} / \mathrm{ml}\right.$.) and the number submitted to the treatment $\left(c .10^{8} / \mathrm{ml}\right.$.). This shows that the period, within one generation, over which bacteria are able to survive a rapid increase in oxygen pressure is so short that even in the synchronized population a minority of the bacteria were in the resistant state.

\section{Catalase synthesis in Bacillus subtilis in relation to the cell cycle}

An oxygen-induced synchronous culture of Bacillus subtilis was used to determine the time of catalase synthesis under atmospheric oxygen conditions; $25 \mathrm{ml}$. samples were withdrawn and chilled to stop metabolism. Because of the slow rate of cooling used for the early samples the cessation of metabolism of these samples was not immediate. Thus, by the time of ultrasonic treatment to extract the catalase, the bacteria would have advanced further in the cell cycle than was indicated by the sampling time. Thus the high value for catalase in sample I (Fig. 5) was probably present in the bacteria just after division rather than during division as the growth curve indicated. In the last four samples a much more rapid rate of cooling was used; 
here the catalase value just began to increase by the start of the second division. Thus the synthesis of catalase occurred early in the cell cycle near the time of maximum resistance to HPO treatment.

\section{DISCUSSION}

The increased value for catalase per bacterium after $48 \mathrm{hr}$ exposure to high-pressure oxygen (HPO) confirmed previous findings (Pritchard \& Hudson, 1967); however, the decrease after $24 \mathrm{hr}$ was unexpected. Furthermore, the lysis of bacteria in the $\mathrm{I} 8 \mathrm{hr}$ cultures subjected to Io atm. seemed at variance with earlier experiments (Caldwell, I965). A partial explanation of these results might be that the bacteria were resistant to the toxic effects of HPO treatment only when in a certain physiological state. Thus in the $\mathrm{I} 8 \mathrm{hr}$ culture in which growth, as indicated by turbidity, was well into the stationary phase, the majority of the bacteria would have been physiologically old. In an actively growing culture only a proportion of the bacteria would be in a resistant state; those not in this state would be killed and there would be an initial decrease in numbers. If the resistant physiological state represents a sufficiently small part of the cell cycle then the growth of an oxygen-treated culture should, on return to air, show some degree of synchrony. Experiments in which growing cultures of Bacillus subtilis and Escherichia coli were treated with oxygen at Io atm. showed this to be the case. The fairly close correspondence between the time of maximum resistance and the time of maximum catalase activity, in $B$. subtilis, supports the hypothesis that catalase forms part of the mechanism of resistance.

Since the mechanism of resistance to HPO is suggested to be enzymic in nature it seems probable that the variation in physiological state is a result of the periodicity of enzyme synthesis. It has been demonstrated that the basal enzyme synthesis of some bacteria is ordered and related to gene position (Masters \& Pardee, 1965), though enzymes of Bacillus subtilis and Escherichia coli may be induced at any time during the cell cycle (Kuempel, Masters \& Pardee, 1965; Masters \& Donachie, 1966; Masters, Kuempel \& Pardee, 1964). Therefore survival of bacteria may be dependent on the active synthesis or presence of a high level of protective enzymes at the time of pressure increase, death of non-resistant bacteria resulting from an irreversible lesion induced more rapidly than, or preventing, the synthesis of protective enzymes.

Further experiments are being conducted to define more closely the role of catalase and investigate the effect of HPO on organisms showing true periodicity of enzyme synthesis.

The author thanks Dr G. G. Pritchard for valuable assistance, particularly during the preparation of this manuscript. This work was supported by a grant from the Science Research Council.

\section{REFERENCES}

Caldwell, J. (1956). Studies in the respiration of apple at various pressures of oxygen. J. exp. Bot. $7,326$.

CALDWELl, J. (1965). Effects of high partial pressures of oxygen on fungi and bacteria. Nature, Lond. 206, 32 I.

HERBERT, D. (1954). Catalase from bacteria (Micrococcus lysodeikticus). Meth. Enzymol. 2, 784.

Kuempel, P. L., Masters, M. \& Pardee, A. B. (I965). Bursts of enzyme synthesis in the bacterial cell cycle. Biochem. biophys. Res. Commun. 18, 858. 
Lowry, O. H., Rosebrough, N. J., Farr, A. L. \& Randall, R. J. (1951). Protein measurement with the Folin phenol reagent. J. biol. Chem. I93, 265.

MASTERS, M. \& DonaChIE, W. D. (I966). Repression and control of cyclic enzyme synthesis in Bacillus subtilis. Nature, Lond. 209, 476.

Masters, M., Kuempel, P. L. \& PARdee, A. B. (1964). Enzyme synthesis in synchronous cultures of bacteria. Biochem. biophys. Res. Commun. $15,38$.

Masters, M. \& Pardee, A. B. (1965). Sequence of enzyme synthesis and gene replication during the cell cycle of Bacillus subtilis. Proc. natn. Acad. Sci., U.S.A. 54, 64.

Pritchard, G. G. (1965). The production of pyruvic and $\alpha$-oxoglutaric acids by Mucor species. J.exp. Bot. 16, 487 .

Pritchard, G. G. \& Hudson, M. A. (1967). Changes in catalase activity in higher plants and fungi treated with oxygen at high pressure. Nature, Lond. 214, 945. 